\title{
Types of word order in poetry
}

\author{
Sobirov Anvar Kuvandikovich ${ }^{1}$ \\ ${ }^{l}$ Doctorate student, Samarkand State University, Uzbekistan \\ Email:sobirova@umail.uz
}

\begin{abstract}
In the syntax, there are two main rules: the usual word order, the unusual (changed) word order. In our opinion, poetry is also relevant in the study of another type of word order, that is, mixed word order. In world and Uzbek linguistics research on word order research, mainly observations on the word order and its types, were based on prose works. For the first time in Uzbek linguistics we studied the vocabulary in poetry.

Keywords: syntax, word order, usual word order, unusual (changed) word order, mixed word order, word order in poetry.

\section{INTRODUCTION}

It consists of grammatically interrelated sections, one in a particular order. The language of words is based on the linguistic regularities, and the expression follows a particular order, according to the logical emphasis of the thought. In the syntax, there are two main rules: the usual word order, the unusual word order. In our opinion, poetry is also relevant in the study of another type of word order, that is, mixed word order.

The order of the word is the arrangement of parts of a sentence in relation to certain syntactic, meaningful values, on the basis of certain grammatical rules. There are a number of conflicting types of speech sections. The most important of these is the opposition of the right and the reverse order. In the correct order, the syntactic parts (slices, pronunciation and other parts of the joint sentence, etc.) are normally placed under certain rules. For example, in the Uzbek language, the correct positioning of the identifier before detection, cross-section of the owner, fill-in, state of the condition is considered to be the correct procedure [UzTME, 2004. Pp. 196].
\end{abstract}

\section{THEORETICAL BACKGROUND}

Let's look at Iqbol Mirza's poem "The Other Way" as an example of poetry:

Қулоғимдан юракка бир сас ўтади.

Шитир-шитир хазон ила хас ўтади,

Хаёт қандай яшамокдан дарс ўтади.

Аммо хаёт бошқа екан, илм бошқа

(Иқбол Мирзо, Сени бугун кўрмасам бўлмас, 86-б).

We can see that the verses of the poem are arranged in the right order from the beginning to the

end.

Inversion is explained in Uzbek linguistics as follows: "Inversion (lat. For example: Where does this old man go in this situation? - Where does this old man go? The asymmetric task is to create composition, weight, rhythm, rhyme in poetry, especially in novels and German. Inversion is not only a methodical event, but also a syntactic-methodical (syntactic-poetic phenomenon), which is more common in live spoken language, in fiction, and especially in poetry. Page 144]

The views of all linguists on the term and its use are consistent.

As an example of a changed vocabulary, let's take a look at Usman Azim's "Bakhshiana Series":

Хақ гап учун хар бир гапга кўнади эл,

Тўғри сўздан кўпаяди, тўлади эл.

Дордан кўрқиб, ёлғон айтиб турганим йўқ, 


\section{Шоирлари ёлғон айтса, ўлади эл}

(Osman Azim, Selected Works, p. 331).

The following poem by Shavkat Rahman describes the pure feelings of the young heart as compared to the natural scenery. It is necessary to check what elements have provided the most attractiveness in it:

Сахар турдим, куёшни кутдим,

Шудрингларга чайдим юзимни.

Булоқларга лабимни тутдим

Ва борликда кўрдим ўзимни... (Shavkat Rahmon, Selection, p. 18).

There are many places in the Egyptian book where Rahman uses both types of vocabulary. As for the four verses above, the first and third verses are in the usual order. It appears that the second fourth passage replaced the place of the same filler. This also has a positive effect on the intonation of the poem. The same order can be called the mixed use of word order in poetry.

\section{THEORETICAL BACKGROUND}

N.A. According to Baskakov, word order is widely used as a syntactic tool, in particular when word syntax functions are not represented by certain morphological indications, word order plays a major role in the syntactic relationship. Indeed, in the relationship between the phrases (concordance, management, adaptation) in the Uzbek language, the subordinate word is associated with the dominant word without the morphological indicators, in order and tone [Baskakov, 1979, p. 116].

K. Hayitmetov divides the word order into the following types in terms of its means:

1. Order in word combinations;

2. The order of the sections;

3. The order of simple sentences in a joint sentence [Hayitmetov, 1984, p. 78].

Based on the above classifications, the word order can be further classified:

1. Order in the parts of the phrase.

2. Order in the parts that make up the section.

3. Sequence in Sections.

4. Arrangement in Compatible Sections and Generalizing Sections.

5. Sequence in separated sections.

6. Sequence in sections that do not have grammatical contact with sections of speech.

7. Sequence in simple sentences within a single sentence.

In his research, I. Mirzayev, in his research, examines the factors contributing to the inversion and the forms of their manifestation, emphasizing the tendency of contact (side-by-side) regulation in attributive phrases [Mirzaev, 1991, p. 37].

The tendency to emphasize words in a poetic speech is the consequence of lack of phrasing and rhythmic grouping (as in prose), which undermines the role of inversion, which is very characteristic of poetry. As a result, every word is cast, bold and resonating. Inversion is a violation of a formal (prose) vocabulary formally, and functionally it is a form of poetic speech.

It is widely used by I. Mirzaev in the system of the order of the main parts of the sentence, where it acts as an important instrument for the coordination of prosodic and rhyming elements, and if the contact inversion aims to highlight one of the parts of the talk, both parts are highlighted in the distant inversion., the analysis has the right word structure and states that the cross section may be separated by one, two or more lines, and several paragraphs In the first verse of the Lord, there is a detailed study of the arrival of the cross in the last line and between them - a formant. The distant positioning of the cross-sectional parts $(-i b+$ verb) draws attention to the remembrance - semantic center of thought and, by its functional function, is equivalent to the stylistic figure of gradation, creating complex syntactic integrity and an important textual tool.

Analysis of word order in poetry allows to differentiate between two main types - right and opposite. Both are equally methodologically neutral and functionally valuable.

Different forms of transformation are used when translating the inversion order. The choice of grammatical transformation depends on the meaning of the sentence and the purpose of the expression. Logical accents are important in oral speech, but if the translation of a word or phrase in the translation 
without paying attention to the logical emphasis, the meaning of the sentence may change. That is why it is necessary to pay attention to the language styles and methodological aspects in translating the changed sentence order.

Discussions in stylistic discourse have always been relevant to linguists. The problems of the semantic relation and location of parts of speech are also being studied by scientists today. Stylistics began by examining "deviations from the norm" as a doctrine of language norms and styles, and their significance in speech. In his work "Essays on English Stylistics, IR Galperin outlined the objectives of this doctrine:" Language stylistics are expressive syntactic means and syntactic-stylistic methods that give a variety of expressions to a neutral form. learns. " [Galperin, 1958: 180]

The order of the words is one of the most important elements of the expression and ensures the development of the theme and the remix. From the stylistic point of view, the order of the sentence serves as an additional coloring of the content, reinforcing or diminishing the meaning of the sentence.

Although the Uzbek language is morphologically aggressive, it is prone to arbitrary variables such as Russian. The English tradition prevailed over the analytical tradition, and the order of the sentences was hardened. The changed sentence sequence is always communicative, expressive, or otherwise loaded, so either direct or indirect translation of the sentence is allowed, resulting in incomplete coverage.

MS Onishenko distinguished eight types of inversion: 1. Local inversion. 2. Exclusive inversion. 3. Inversion for equilibrium. 4. Denial inversion. 5. Heavy inversion. 6. Inversion involving interrogations used with no words. 7. Inversion of interrogation. 8. Steady-state inversion [Onishchenko, 2010: 99-105]: In Uzbek, as in Russian, the inversion is unique. Usually Russian is classified as a "free" language. Therefore, such syntactic content allows for a voluntary repositioning of a sentence.

Based on the classification of E.A Lutyutova, the inversion phenomenon can be divided into two types: compositional and derivative.

In a compositional approach, some of the elements that make up the sentence have a free role. For example, two fillers can be linked directly to one verb directly or indirectly: the verb tags the mediator, then the intermediary, or the verb unplugged, then

Uktam handed the book to the Queen;

Uktam handed the book to the princess.

The derivative approach uses some pre-existing and ready-to-use units. Inversion is produced by deviation from the finished order. The advantage of the derivative approach is that it allows the use of single base structures to generate different types of inversions. The positive side of this approach is also the discovery of similarities between rhetoric and fluent speech. Furthermore, if the compositional approach does not restrict the use of "free speech", the principles of derivation and motivation of action within the derivative approach are used.

Although the Uzbek language is morphologically far from Russian and English, it can express almost all types of inversion, with no difficulty in translation.

The following are the conclusions regarding the types of word order in Uzbek: In the world and Uzbek linguistics research on the study of vocabulary is mainly based on the prose works. For the first time in Uzbek linguistics we studied the order of words in poetry.

\section{CONCLUSION}

In Uzbek linguistics, the order of words in poetry was first put forward as a matter that should be studied separately by I. Mirzaev. In other studies, only certain statements were given, such as the definition of the word order, the feedback on inversion, the analysis of the types of vocabulary, and the actual division of the sentence.

I.Mirzaev and K.Haitmetov's classifications regarding the types of words are based on their functions. MS Onishenko's classification of inversion types can also be used to analyze the changed vocabulary in Uzbek.

\section{REFERENCES}

1. Baskakov N.A. et al. General linguistics. - Tashkent: Instructor, 1979, -186 p.

2. Mirzaev IK Problemy lingvopoeticheskoy interpretations stixotvornogo texa: autoref. diss. ... Doc. filol. nauk. - Tashkent, 1991. - 52 p. 
3. The National Encyclopedia of Uzbekistan. 12 drops. - Tashkent: State Scientific Publishing House of the National Encyclopedia of Uzbekistan, 2002-2006- 926 p.

4. Shavkat Rahman through the Eternal. Elections. - Tashkent: East NMAK, 2012. - 462 p.

5. Osman Azim. Selected works. Volume 1 - Tashkent: Gafur Gulom Publishing House, 2016. 479 p.

6. Hayitmetov K. Topical division and position issues in the Uzbek language. - Tashkent, Science, 1984. - 159 p. 